\title{
Effect of slow release urea in sheep feed on intake, nutrient digestibility, and ruminal parameters
}

\section{Ureia de liberação lenta na alimentação de ovinos sobre o consumo e coeficiente de digestibilidade dos nutrientes e parâmetros ruminais}

\author{
Luiz Juliano Valério Geron ${ }^{1 *}$; Ślvia Cristina de Aguiar ${ }^{1}$; \\ Joilma Toniolo Honório de Carvalho ${ }^{2}$; Gregory Duarte Juffo ${ }^{1}$; Ana Paula da Silva \\ Eurico Lucas de Sousa Neto ${ }^{1}$; Kallynka Samara Martins Coelho ${ }^{2}$; Jocilaine Garcia ${ }^{1}$; \\ Leomar Custódio Diniz²; Edson Júnior Heitor de Paula ${ }^{1}$
}

\begin{abstract}
This study aimed to evaluate the inclusion of $0.0 \%, 0.4 \%, 0.8 \%$, and $1.2 \%$ slow release urea (SRU) in sheep feed on the intake and total digestibility coefficient (DC) of nutrients and ruminal parameters of sheep living in tropical regions. Four sheep with a body weight (BW) average of $30.8 \pm 1.7 \mathrm{~kg}$ were assigned to a Latin square design. The animals were placed in metabolic cages and received two meals a day. Intake data and DC of nutrients of the sheep were subjected to analysis of variance and differences were tested using a regression equation to $5 \%$ probability. The inclusion of $0.0 \%, 0.4 \%, 0.8 \%$, and $1.2 \%$ SRU in sheep feed did not change ( $p>0.05)$ the intake of dry matter $(\mathrm{DM})$, organic matter $(\mathrm{OM})$, crude protein (CP), ether extract (EE), neutral or acid detergent fiber (NDF, ADF), total carbohydrates (TC), and

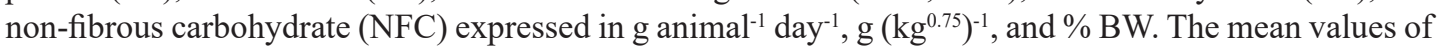
$3.04 \%, 2.82 \%, 0.41 \%, 0.07 \%, 1.36 \%, 0.87 \%, 2.31 \%$, and $1.00 \%$ of $\mathrm{BW}$ were obtained for the intake of $\mathrm{DM}, \mathrm{OM}, \mathrm{CP}, \mathrm{EE}, \mathrm{ANF}, \mathrm{ADF}, \mathrm{TC}$, and NFC, respectively. The inclusion of $0.0 \%, 0.4 \%, 0.8 \%$, and $1.2 \%$ of SRU in sheep rations had a quadratic manner $(\mathrm{p}<0.05)$ the $\mathrm{DC}$ of DM and $\mathrm{CP}$, with maximum values of $69.67 \%$ and $63.59 \%$, respectively, for $0.51 \%$ and $0.66 \%$ levels of SRU inclusion in the experimental diets. The $\mathrm{pH}$ of the rumen fluid did not vary $(\mathrm{p}>0.05)$ for different levels of inclusion of SRU in the feed. However, the $\mathrm{pH}$ of the rumen fluid did differ $(\mathrm{p}<0.05)$ in relation to time $(\mathrm{T})$ after feeding for all experimental diets. The inclusion levels of SRU in sheep feed did not affect $(p>0.05)$ the concentration of ammonia nitrogen $\left(\mathrm{NH}_{3}-\mathrm{N}\right)$ of the rumen fluid, but there was a quadratic effect $(\mathrm{p}<0.05)$ with relation to $\mathrm{T}$ for all experimental diets. Thus, we conclude that the inclusion of $0.66 \%$ SRU provides the best digestibility value of $\mathrm{CP}$ and is the appropriate value for the digestion of DM. The inclusion of up to $1.2 \%$ of SRU in sheep rations did not change the intake of nutrients and ruminal parameters.
\end{abstract}

Key words: Crude protein. Dry matter. Feces. Non-protein nitrogen.

\section{Resumo}

Objetivou-se avaliar a inclusão de $0,0 \% ; 0,4 \% ; 0,8 \%$ e $1,2 \%$ de ureia de liberação lenta (ULL) na alimentação de ovinos em região tropical sobre o consumo e o coeficiente de digestibilidade total (CD)

\footnotetext{
${ }^{1}$ Profs., Universidade do Estado de Mato Grosso, UNEMAT, Pontes e Lacerda, MT, Brasil. E-mail: ljgeron@yahoo.com.br; scaguia@unemat.br; juffomv@unemat.br; euriconeto@unemat.br; jo@unemat.br; edsonjr@unemat.br

2 Discentes do Curso de Bacharelado em Zootecnia, UNEMAT, Pontes e Lacerda, MT, Brasil. E-mail: joilma_thc@hotmail.com; coelho-ksm@hotmail.com; leomarfig@hotmail.com

${ }_{3}$ Discente do Curso de Mestrado, Programa de Pós-Graduação em Ciências Animal, Universidade Federal da Grande Dourados, UFGD, Dourados, MS, Brasil. E-mail: anapaula2886@gmail.com

* Author for correspondence
} 
dos nutrientes e parâmetros ruminais. Foram utilizados quatro ovinos com peso corporal (PC) médio de $30,8 \pm 1,7 \mathrm{~kg}$, distribuídos em um delineamento em quadrado latino. Os ovinos foram alocados em gaiolas de metabolismo e receberam duas refeições por dia. Os dados de consumo e CD dos nutrientes dos ovinos foram submetidos à análise de variância e as diferenças observadas foram testadas com utilização de equação de regressão a $5 \%$ de probabilidade. A inclusão $0,0 \% ; 0,4 \% ; 0,8 \%$ e $1,2 \%$ de ULL na alimentação de ovinos não alterou $(\mathrm{p}>0,05)$ o consumo de matéria seca (MS), matéria orgânica $(\mathrm{MO})$, proteína bruta $(\mathrm{PB})$, extrato etéreo (EE), fibra em detergente neutro (FDN) e ácido (FDA),

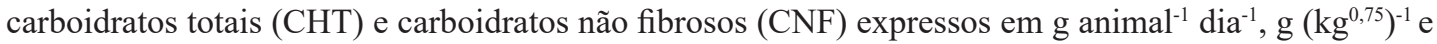
$\%$ PC. Os valores médios de 3,04\%; $2,82 \% ; 0,41 \% ; 0,07 \% ; 1,36 \% ; 0,87 \% ; 2,31 \%$ e $1,00 \%$ do PC foram obtidos para o consumo de MS; MO; PB; EE; FDN; FDA, CHT e CNF, respectivamente. A inclusão de $0,0 \% ; 0,4 \% ; 0,8 \%$ e $1,2 \%$ de ULL nas rações de ovinos influenciou de maneira quadrática $(\mathrm{p}<0,05)$ o CD da MS e PB, com valores de máximo de $69,67 \%$ e $63,59 \%$, respectivamente para os níveis de 0,51 e $0,66 \%$ de inclusão de ULL nas rações experimentais. Os valores de $\mathrm{pH}$ do líquido ruminal não diferiram ( $>0,05$ ) para os níveis de inclusão da ULL na alimentação de ovinos. Contudo, o pH do líquido ruminal diferiu de maneira quadrática $(\mathrm{p}<0,05)$ em relação ao tempo $(\mathrm{T})$ após a alimentação, para todas as rações experimentais. Os níveis de inclusão da ULL na alimentação dos ovinos não influenciaram ( $>0,05)$ a concentração de nitrogênio amoniacal $\left(\mathrm{N}^{-\mathrm{NH}_{3}}\right)$ do líquido ruminal, contudo houve efeito quadrático $(p<0,05)$ com relação ao tempo para todas as rações experimentais. Desta maneira, conclui-se a inclusão de $0,66 \%$ da ureia de liberação lenta propicia o melhor dados de coeficiente de digestibilidade da proteína bruta e teor adequado para a digestão da matéria seca. A inclusão de 1,2\% de ureia de liberação lenta não altera o consumo dos nutrientes e os parâmetros ruminais.

Palavras-chave: Fezes. Matéria seca. Nitrogênio não proteico. Proteína bruta.

\section{Introduction}

Protein requirements in ruminants, as in other animals, are met by amino acids absorbed by the small intestine, though the majority of absorbable protein $(50-80 \%)$ arises from microbial protein (MicP) synthesized in the rumen (BACH et al., 2005).

The concept of using non-protein nitrogen (NPN) has progressed greatly in recent years. In the past, it was used as much as possible, the NPN in replacing of true protein because it did not affect the production and health of the animals. In addition, the substitution of NPN for vegetable or animal protein in the diet decreases the cost of nitrogen, and as a consequence, the price of feed (MENDES et al., 2010; OLIVEIRA et al., 2001; SILVEIRA et al., 2012).

The concept that the ammonia nitrogen $\left(\mathrm{NH}_{3}-\mathrm{N}\right)$ release rate should match the carbohydrate digestion rate has become increasingly important (CASTANEDA et al., 2009) and has led the industry to pursue the development of slow-release NPN compounds with less risk of poisoning (PIRES et al., 2004). In recent years, several sources of NPN were evaluated as alternatives to replace urea, and among the best known are the biuret, creatinine, the diureido, and isobutane, as well as other products in the experimental test phase (PIRES et al., 2004; XIN et al., 2010).

Finding effective methods of protecting urea has been a challenge, and therefore the industry has developed compounds with polymers (Optigen ${ }^{\circledR}$ and Optigen ${ }^{\circledR} 1.200$ ) and polyurethane (XIN et al., 2010), encapsulated urea (TAYLOR-EDWARDS et al., 2009), and urea physically encapsulated by vegetable waxes (Optigen ${ }^{\circledR}$ RII), among others.

The use of NPN of gradual and/or slow release in the rumen can be a strategy to reduce the use of true protein sources and livestock urea in ruminant diets, with advantages including reducing the risks of urea intoxication, increasing space for the inclusion of other ingredients in the diet, replacing true protein sources that are of high cost and limited availability, and improving the synchronization of nutrients in the rumen, without compromising the production performance of ruminants (SOUZA et al., 2010). 
Optigen ${ }^{\circledR}$ is a pelleted urea that is covered with a biodegradable polymer capable of controlled release. This highly concentrated source of nitrogen $(42 \% \mathrm{~N})$ can alter rumen function by providing nitrogen to rumen bacteria at a speed that optimizes its conversion into microbial protein (MARTHA, 2013).

Puga et al. (2001) evaluated sheep fed diets containing both high forage and protected urea and found a significant increase in the intake and digestibility of nutrients with the inclusion of the protected urea, which is likely because optimal microorganism activity in fiber fermentation occurred in the rumen.

However, Paris et al. (2013) studied the use of slow-release urea (SRU) in mineral salt supplementation of cattle grazing Tifton 85, and showed that the replacement of common urea by SRU resulted in no increase in average daily gain and gain by area. For this reason, the authors recommended the use of mineralized salt with common urea because it costs less.

A study conducted by Akay et al. (2004) evaluated the in situ degradation of SRU (Optigen ${ }^{\circledR}$ ) compared to common urea, soybean meal, and soybean grain, and showed that SRU had a disappearance curve similar to that of soybean meal, but slower than common urea, with an intermediate rate of disappearance in the first 16 hours of rumen fermentation, followed by a slow disappearance rate between 16 to 30 hours, similar to that observed for soybean meal.

In an evaluation of sheep fed diets containing SRU (which replaced conventional urea) on nitrogen metabolism and microbial synthesis, the substitution of common urea by SRU did not alter intake, fecal and urinary excretion of nitrogen, and the synthesis and microbial efficiency (ALVES et al., 2014a). Thus, the authors recommended that common urea should be used for sheep in confinement.
Silveira et al. (2012) evaluated the partial substitution of soybean meal by SRU in commercial dairy herds and found that the use of Optigen ${ }^{\circledR}$ (SRU) in the diets of lactating cows provided more ruminal nitrogen because of the continuous supply of $\mathrm{N}$ from the SRU, which resulted in similar milk production and an increase in protein synthesis in the microbial rumen, without inducing increased milk urea nitrogen. The authors also concluded that every $150 \mathrm{~g}$ of SRU in dairy cow diets replaced 1.0 $\mathrm{kg}$ of soybean meal in the ration, and in this way, when soybean meal is expensive, the inclusion of SRU in diets of dairy cows is economically more profitable.

In summary, SRU contributes available $\mathrm{N}$ to the rumen more slowly than urea, but faster than the $\mathrm{N}$ of protein foods of vegetable origin. This study aimed to evaluate the inclusion of SRU $\left(\right.$ Optigen $\left.{ }^{\circledR}\right)$ in sheep feed on consumption, nutrient digestibility, and ruminal parameters ( $\mathrm{pH}$ and $\mathrm{NH}_{3}-\mathrm{N}$ concentration) of sheep in tropical regions.

\section{Material and Methods}

The study was conducted at the University Campus of Pontes e Lacerda in Setor de Metabolismo Animal (SeMA) and in Laboratório de Análise de Alimentos e Nutrição Animal (LAANA) belonging to Universidade do Estado de Mato Grosso (UNEMAT). The climate is classified as Tropical Continental, alternately wet and dry Aw second Koppen (GERON et al., 2015a). Room temperature values, maximum and minimum temperature, dry and wet bulb, and relative humidity for the execution period of the study are shown in Table 1.

Four mixed breed castrated sheep with a body weight (BW) average of $30.8 \pm 1.7 \mathrm{~kg}$ were used in the experiment. The sheep were housed in metabolic cages that had individual feeders and waterers. Fifteen days before the beginning of the trial period, the sheep were wormed with Ivermectina ${ }^{\circledR}$ based products. 
A Latin square $(4 \times 4)$ design was used with four animals, four periods, and four experimental diets with varying inclusion levels of SRU in order to evaluate the effects of SRU on the intake and coefficient of total digestibility of nutrients and ruminal fermentation in sheep.

Table 1. Ambient temperature and relative humidity for the trial of sheep fed diets containing inclusion levels of slow release urea (SRU) in the state of Mato Grosso.

\begin{tabular}{lcccccc}
\hline \multirow{2}{*}{ Period } & \multicolumn{7}{c}{ Ambient weather variables } \\
\cline { 2 - 7 } & RT & RT min & RT max & DBT & WBTU & RU (\%) \\
\hline Morning & 23.15 & - & - & 25.30 & 22.05 & 75.00 \\
Afternoon & 34.75 & - & - & 40.35 & 31.85 & 52.00 \\
Average & 28.95 & 22.60 & 36.83 & 32.83 & 26.95 & 63.50 \\
\hline
\end{tabular}

RT: room temperature; RT min: minimum temperature; RT max: maximum temperature; DBT: dry bulb temperature; WBT: wet bulb temperature and RH: relative humidity in $\%$.

The SRU was acquired in the local market in the state of Mato Grosso, and the trade name of the product evaluated was Optigen ${ }^{\circledR}$. Inclusion levels of $0.0 \%, 0.4 \%, 0.8 \%$, and $1.2 \%$ of SRU in the DM were used, and the maximum level of inclusion of SRU in the experimental ration represented a value of $57 \%$ of nitrogen from the replacement of soybean meal by NPN. The inclusion levels of SRU in the sheep feed were based on a literature review that showed that the inclusion of $0.4 \%$ of
SRU in dairy cows did not alter nutrient intake and milk production (SOUZA et al., 2010). In addition, Alves et al. (2014b) showed that the substitution of conventional urea by SRU in $80 \%$ of sheep feed led to a reduction in carcass yield and subcutaneous fat.

The feed concentrates used in the preparation of the experimental diets were ground grain corn, soybean meal, and SRU $\left(\right.$ Optigen $\left.^{\circledR}\right)$, and the roughage provided to the animals was corn silage. The chemical composition of the foods is shown in Table 2.

Table 2. Chemical composition of the experimental foods.

\begin{tabular}{lcccc}
\hline \multicolumn{1}{c}{ Variables } & \multicolumn{4}{c}{ Experimental foods } \\
\cline { 2 - 4 } \multicolumn{1}{c}{$\mathrm{CS}^{1}$} & $\mathrm{CGG}^{2}$ & $\mathrm{SM}^{3}$ & $\mathrm{SRU}^{4}$ \\
\hline Dry matter \% & 28.40 & 91.68 & 90.35 & 100.00 \\
Organic matter \% & 92.16 & 97.22 & 93.37 & 99.00 \\
Crude protein \% & 8.25 & 9.83 & 47.55 & 282.00 \\
Ether extract \% & 1.61 & 4.34 & 1.51 & -5 \\
Neutral detergent fiber \% & 68.58 & 13.63 & 17.80 & - \\
Acid detergent fiber \% & 41.03 & 11.31 & 16.66 & - \\
Total carbohydrates \% & 82.30 & 83.05 & 44.31 & - \\
No-fibrous carbohydrate \% & 13.72 & 69.42 & 26.51 & - \\
Mineral matter \% & 4.79 & 2.78 & 6.38 & - \\
Total digestible nutrients \% & 62.30 & 86.03 & 80.73 & - \\
\hline
\end{tabular}

1CS: corn silage, $2 \mathrm{CGG}$ : corn grain ground, ${ }^{3} \mathrm{SM}$ : soybean meal, ${ }^{4} \mathrm{SRU}$ : slowly release of urea (Optigen $\left.{ }^{\circledR}\right) ;{ }^{5}$ nutrient trace within the experimental food. 
The roughage:concentrate used was 65:35. The diets were balanced to submit on average 14.0\% of crude protein (isoproteic) and $69.5 \%$ of total digestible nutrients (isoenergetic), as recommended by the NRC (2007) for a net gain of $100 \mathrm{~g}$ animal $^{-1}$ day $^{-1}$ to castrated sheep (Table 3 ).
The sheep had access to water via individual troughs. Ten grams of mineral mixture per animal was fed daily and added directly to the concentrate at the time of feeding. Twice daily, $5 \mathrm{~g}$ salt meal ${ }^{-1}$ animal ${ }^{-1}$ was provided. The chemical composition of the mineral salt used in this study was $120 \mathrm{~g} \mathrm{Ca} \mathrm{kg}^{-1}$; $85 \mathrm{~g} \mathrm{P} \mathrm{kg}^{-1}$; $16 \mathrm{~g} \mathrm{~S} \mathrm{~kg}^{-1}$; $148 \mathrm{~g} \mathrm{Na} \mathrm{kg}^{-1}$; $50 \mathrm{mg} \mathrm{Co} \mathrm{kg}{ }^{-1}$;

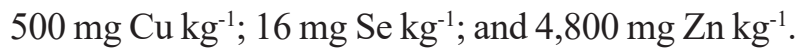

Table 3. Percentage and chemical composition of the experimental rations containing different levels of inclusion of the slowly release of urea (SRU) provided to sheep.

\begin{tabular}{lcccc}
\hline \multirow{2}{*}{ Foods } & \multicolumn{3}{c}{ Inclusion levels of slowly release of urea in the experimental rations } \\
\cline { 2 - 5 } & $0.0 \%$ & $0.4 \%$ & $0.8 \%$ & $1.2 \%$ \\
\hline Corn silage & 65.00 & 65.00 & 65.00 & 65.00 \\
Corn grain ground & 22.00 & 24.10 & 26.10 & 28.30 \\
Soybean meal & 13.00 & 10.50 & 8.10 & 5.50 \\
Slowly release of urea (Optigen) & 0.00 & 0.40 & 0.80 & 1.20 \\
\hline Total & 100.00 & 100.00 & 100.00 & 100.00 \\
\hline Chemical composition expressed in \% & & & & \\
Dry matter & 50.38 & 50.44 & 50.51 & 50.57 \\
Organic matter & 93.43 & 93.53 & 93.63 & 93.74 \\
Crude protein & 13.71 & 13.85 & 14.04 & 14.14 \\
Ether extract & 2.20 & 2.25 & 2.30 & 2.36 \\
Neutral detergent fiber & 49.89 & 49.73 & 49.58 & 49.41 \\
Acid detergent fiber & 31.32 & 31.14 & 30.97 & 30.79 \\
Total carbohydrates & 77.53 & 78.16 & 78.76 & 79.44 \\
No-fibrous carbohydrate & 27.64 & 28.43 & 29.18 & 30.02 \\
Mineral matter & 4.55 & 4.45 & 4.36 & 4.25 \\
Total digestible nutrients & 69.92 & 69.70 & 69.49 & 69.28 \\
\hline
\end{tabular}

The rations were provided at will (ad libitum), but the remains were controlled so that they were approximately $10.0 \%$, which standardized the delivery of food and avoided wasting, but still allowed the animal to reach its daily ingestive capacity. The experimental diets were divided into two meals a day and provided at $06 \mathrm{~h}$ and $18 \mathrm{~h}$. The monitoring of food remains was carried out daily before the first meal of the day.

The nutrient digestibility trial lasted 84 days, and was divided into four periods lasting 21 days (i.e., 15 days for animal adaptation, 5 days for the collection of food remains and feces samples, and a day of ruminal fluid collection). During the collection period, total feces and food remains generated per animal day-1, beyond sampling of food were measureds. In the period of adaptation and collection, management was performed as described by Geron et al. (2013).

A napa bag was adapted and used to collect all feces during the experimental period from each animal. The feces of the animals were weighed every morning and homogenized, and composite samples corresponding to $10 \%$ of the total sample weight 
were taken (GERON et al., 2015a). The samples of feces were placed in plastic bags, identified per animal and experimental period, and stored in a freezer at $-10^{\circ} \mathrm{C}$ for further analysis.

On the last day of each collection period, samples of ruminal fluid were collected. The samples were taken before the first feeding $(6 \mathrm{~h})$, which was established as time zero (0), and then at 2, 4, 6, and $8 \mathrm{~h}$ post feeding, with five samples per animal per period. A vacuum pump (40 $\mathrm{mm} \mathrm{Hg}$ pressure) attached to a silicone hose $(2.0 \mathrm{~m}$ long $\times 12.0 \mathrm{~mm}$ diameter) lubricated with mineral oil (Nujol) was introduced into the mouth of the animal (GERON et al., 2015b) and used to collect the samples. For $\mathrm{NH}_{3}-\mathrm{N}$ determination, the sample was filtered to obtain $100 \mathrm{~mL}$ of ruminal fluid. Immediately after collection, the $\mathrm{pH}$ of the sample was measured from $50 \mathrm{~mL}$ of ruminal fluid using a digital $\mathrm{pH}$ meter. One milliliter of sulfuric acid $\left(\mathrm{H}_{2} \mathrm{SO}_{4}, 1: 1\right)$ was then added to stop fermentation. The $\mathrm{NH}_{3}-\mathrm{N}$ level was determined by distillation with potassium hydroxide $2 \mathrm{~N}$, using the method described by Fenner (1965), and later modified by Vieira (1980).

Samples of food, remnants, and feces were dried at $55^{\circ} \mathrm{C}$ for 72 hours and processed in a Wiley mill using a $1 \mathrm{~mm}$ sieve and then homogenized in equal amounts, based on dry weight, to form composite samples of feces remnants and food, per period experimental ${ }^{-1}$ animal $^{-1}$ experimental rations ${ }^{-1}$.

Samples of food, remnants, and feces were subjected to analysis of dry matter (DM - method 934.01), organic matter (OM - method 924.05), crude protein (CP - method 920.87), and ether extract (EE - method 920.85) according to AOAC (1990).

The determination of the neutral detergent fiber (NDF) of the food, remnants, and feces was performed according to Van Soest et al. (1991), without the use of sulfite and without correcting the NDF with respect to the mineral matter content of the fiber. The acid detergent fiber (ADF) was carried out according to method 973.18 (AOAC, 1990).
The determination of total carbohydrates (TC) of the food, remnants, and feces was obtained by the equation: $\mathrm{TC}=\mathrm{OM}-[\mathrm{EE}+\mathrm{CP}](\mathrm{SNIFFEN}$ et al., 1992). The non-fiber carbohydrate content (NFC) of the food, remnants, and feces was determined by the equation: $\mathrm{NFC}=100-(\mathrm{CP}+\mathrm{NDF}+\mathrm{EE}+\mathrm{MM})$, wherein the MM: mineral material second Sniffen et al. (1992).

The determination of the total digestibility coefficient (DC) of nutrients was obtained by the equation: [((nutrient contained in feed supplied $\mathrm{g}$ - remnants of nutrient $\mathrm{g}$ ) - nutrient contained in feces $\mathrm{g}$ ) / intake of nutrient $\mathrm{g}] \times 100$ as described by Geron et al. (2015a).

The variables were subjected to analysis of variance through the SAEG software (UFV, 2007), with a $\mathrm{p}$ value of 0.05 considered significant. When significant effects of inclusion levels of SRU in the experimental feeds were observed, regression analysis was then performed, with the linear and quadratic effect considered at 5\% significance. For the $\mathrm{pH}$ and concentration of ammonia in the rumen fluid, statistical analysis that considered the subdivision of the parcel was undertaken, which included the time of evaluation after feeding the animals. This method of frequentist analysis, was considered with the regression for each level of inclusion of SRU beyond the average of experiments rations (SOUZA et al., 2016).

\section{Results and Discussion}

Inclusion levels of $0.0 \%, 0.4 \%, 0.8 \%$, and $1.2 \%$ of SRU in sheep feeding did not change $(p>0.05)$ the intake of DM, OM, CP, EE, NDF, ADF, TC, and CNF (Table 4). The average values for the intake of DM, OM, CP, EE, NDF, ADF, TC, and NFC were 927.80, 868.67, 127.97, 21.86, 418.59, 267.52, 713.62 , and $307.40 \mathrm{~g} \mathrm{animal}^{-1}$ day $^{-1}$, respectively. The replacement of soybean meal (true protein) by SRU, which has a disappearance rate similar to that of soybean meal (AKAY et al., 2004), may have contributed to the maintenance of the rumen 
environment (MARTHA, 2013) and the average results observed for the intake of the different nutrients of the experimental rations in the present study.

The average values of intake of the different nutrients in the experimental rations were consistent with those reported in the literature for diets containing 13 to $15 \%$ crude protein and diets containing 35 to $50 \%$ concentrate, with a DM intake variation of 580.56 to $1371.44 ; \mathrm{OM}, 553.14$ to 1346.10; and CP, 77.37 to 352.24 , expressed in $\mathrm{g}$ animal $^{-1}$ day $^{-1}$ (GERON et al., 2013, 2015a; PRADO et al., 2004).

Table 4. Daily average intake of dry matter (IDM), organic matter (IOM), crude protein (ICP), ether extract (IEE), neutral detergent fiber (INDF) and acid (IADF), total carbohydrates (ITC), and non-fiber carbohydrates (INFC) by sheep fed with rations containing slowly release of urea (SRU).

\begin{tabular}{|c|c|c|c|c|c|c|}
\hline \multirow[t]{2}{*}{ Variables } & \multicolumn{4}{|c|}{$\begin{array}{c}\text { Inclusion levels of the slowly release of urea in } \\
\text { experimental rations }\end{array}$} & \multirow[t]{2}{*}{ Regres. } & \multirow[t]{2}{*}{ CV $(\%)$} \\
\hline & $0.0 \%$ & $0.4 \%$ & $0.8 \%$ & $1.2 \%$ & & \\
\hline IDM g animal $^{-1}$ day $^{-1}$ & 946.37 & 956.80 & 971.77 & 836.26 & $\mathrm{Y}=927.80$ & 13.37 \\
\hline IDM \% BW & 3.09 & 3.20 & 3.12 & 2.76 & $\mathrm{Y}=3.04$ & 17.56 \\
\hline IDM $g\left(\mathrm{~kg}^{0,75}\right)^{-1}$ & 72.68 & 72.25 & 73.71 & 64.74 & $Y=70.85$ & 14.47 \\
\hline IOM g animal $^{-1}$ day $^{-1}$ & 886.78 & 895.82 & 904.59 & 787.51 & $Y=868.67$ & 13.14 \\
\hline IOM \% BW & 2.90 & 2.86 & 2.91 & 2.60 & $\mathrm{Y}=2.82$ & 14.79 \\
\hline $\operatorname{IOM} \mathrm{g}\left(\mathrm{kg}^{0,75}\right)^{-1}$ & 68.11 & 67.65 & 68.68 & 60.97 & $Y=66.35$ & 14.33 \\
\hline ICB g animal ${ }^{-1}$ day $^{-1}$ & 129.10 & 132.22 & 134.51 & 116.03 & $Y=127.97$ & 13.00 \\
\hline ICP \% BW & 0.42 & 0.42 & 0.43 & 0.38 & $\mathrm{Y}=0.41$ & 14.46 \\
\hline $\operatorname{ICP} g\left(\mathrm{~kg}^{0,75}\right)^{-1}$ & 9.91 & 9.99 & 10.21 & 8.98 & $Y=9.77$ & 14.02 \\
\hline IEE $g$ animal ${ }^{-1}$ day $^{-1}$ & 22.16 & 21.65 & 21.95 & 21.68 & $\mathrm{Y}=21.86$ & 14.33 \\
\hline IEE \% BW & 0.072 & 0.069 & 0.071 & 0.071 & $\mathrm{Y}=0.071$ & 16.74 \\
\hline $\operatorname{IEE} \mathrm{g}\left(\mathrm{kg}^{0,75}\right)^{-1}$ & 1.70 & 1.63 & 1.66 & 1.68 & $\mathrm{Y}=1.66$ & 16.11 \\
\hline INDF $g$ animal $^{-1}$ day $^{-1}$ & 422.21 & 459.54 & 413.81 & 378.78 & $Y=418.59$ & 19.77 \\
\hline INDF \% BW & 1.38 & 1.47 & 1.34 & 1.23 & $\mathrm{Y}=1.36$ & 20.96 \\
\hline INDF $g\left(\mathrm{~kg}^{0,75}\right)^{-1}$ & 32.45 & 34.97 & 31.53 & 29.33 & $\mathrm{Y}=32.00$ & 20.63 \\
\hline IADF $g$ animal $^{-1}$ day $^{-1}$ & 277.43 & 264.00 & 267.83 & 260.83 & $Y=267.52$ & 12.66 \\
\hline ISDF \% BW & 0.91 & 0.84 & 0.91 & 0.86 & $\mathrm{Y}=0.87$ & 14.20 \\
\hline IADF $g\left(\mathrm{~kg}^{0,75}\right)^{-1}$ & 21.31 & 19.90 & 20.31 & 20.21 & $\mathrm{Y}=20.43$ & 13.75 \\
\hline ITC $g$ animal $^{-1}$ day $^{-1}$ & 735.52 & 690.50 & 755.32 & 673.13 & $Y=713.62$ & 11.68 \\
\hline ITC \% BW & 2.40 & 2.20 & 2.43 & 2.22 & $\mathrm{Y}=2.31$ & 12.88 \\
\hline ITC $\mathrm{g}\left(\mathrm{kg}^{0,75}\right)^{-1}$ & 56.50 & 52.12 & 57.40 & 52.12 & $Y=54.53$ & 12.50 \\
\hline INFC $g$ animal $^{-1}$ day $^{-1}$ & 313.31 & 289.91 & 325.58 & 300.80 & $Y=307.40$ & 6.46 \\
\hline INFC \% BW & 1.02 & 0.93 & 1.05 & 0.99 & $\mathrm{Y}=1.00$ & 9.01 \\
\hline INFC $g\left(\mathrm{~kg}^{0,75}\right)^{-1}$ & 24.05 & 21.92 & 24.74 & 23.29 & $\mathrm{Y}=23.50$ & 8.32 \\
\hline
\end{tabular}

$\mathrm{g}\left(\mathrm{kg}^{0,75}\right)^{-1}$ : grams per kilogram of metabolic weight; \% BW: body weight; $\mathrm{g}$ animal ${ }^{-1}$ day $^{-1}$ : grams animal per day; Regres.: regression equation; and \% CV: coefficient of variation.

Likewise, a study by Alves et al. (2014a) that assessed the nitrogen metabolism and microbial synthesis of sheep with a body weight of $21 \mathrm{~kg}$ fed diets containing 20 to $80 \%$ replacement of soybean meal by SRU, showed that the substitution of soybean meal by SRU did not change the intake of 
PB, with an average of $133.69 \mathrm{~g}^{\text {animal }}{ }^{-1}$ day $^{-1}$, a value similar to that observed in this study $(127.97 \mathrm{~g}$ animal $^{-1}$ day $^{-1}$ ) (Table 4). This observation supports the use of SRU in ruminant feed as a substitute for true protein (soybean meal), which has a high commercial value, especially during the soybean of season.

Inclusion levels of $0.0 \%, 0.4 \%, 0.8 \%$, and $1.2 \%$ SRU in sheep feed did not change $(\mathrm{p}>.05)$ the DC of the OM, EE, NDF, ADF, TC, and NFC (Table 5). The average figures for the DC of the OM, EE, NDF, ADF, TC, and NFC were 70.40\%, 85.54\%, 44.87\%, $36.32 \%, 71.84 \%$, and $96.23 \%$, respectively.

However, the inclusion levels of the SRU in sheep feed changed $(p<0.05)$ the DC of the DM and $\mathrm{CP}$ in a quadratic manner (Table 5). The highest points of the DC of DM and CP obtained were $69.92 \%$ and $63.55 \%$, respectively, for the inclusion levels of the SRU of 0.51 and $0.66 \%$, respectively.

The highest value for the DC of CP of $63.55 \%$ estimated by the regression equation for the level of $0.66 \%$ SRU was below the average of $72.98 \%$ for the DC of CP found by Alves et al. (2014a) who evaluated the replacement of true protein (soybean meal) by SRU. Most likely, the greater body weight of the animals in this study provided a lower DC value of CP in relation to those values reported in the literature. However, for sheep with a body weight of $30.8 \mathrm{~kg}$, a level of $0.66 \%$ SRU corresponded to a replacement of approximately $33.08 \%$ of true protein (soybean meal), which resulted in the best value for the digestibility coefficient of CP (Table 5).

Table 5. Coefficients of variation (CV) and total digestibility coefficients (DC) for dry matter (DM), organic matter $(\mathrm{OM})$, crude protein $(\mathrm{CP})$, ether extract (EE), neutral detergent fiber (NDF) and acid fiber (ADF), total carbohydrates (TC) and non-fibrous carbohydrate (NFC) for sheep fed with rations containing slowly release of urea (SRU).

\begin{tabular}{|c|c|c|c|c|c|c|}
\hline \multirow[t]{2}{*}{ Variables } & \multicolumn{4}{|c|}{$\begin{array}{c}\text { Inclusion levels of the slowly release of urea in } \\
\text { experimental rations }\end{array}$} & \multirow[t]{2}{*}{ Regres. } & \multirow[t]{2}{*}{$\mathrm{CV} \%$} \\
\hline & $0.0 \%$ & $0.4 \%$ & $0.8 \%$ & $1.2 \%$ & & \\
\hline$\overline{\mathrm{DCDM}}$ & 66.82 & 66.87 & 71.88 & 63.28 & 1 & 5.02 \\
\hline DCOM & 7047 & 69.01 & 73.93 & 68.18 & $\mathrm{Y}=70.40$ & 4.67 \\
\hline DCCP & 52.16 & 59.26 & 65.47 & 54.79 & 2 & 10.08 \\
\hline DCEE & 82.37 & 89.01 & 86.57 & 84.21 & $Y=85.54$ & 10.16 \\
\hline DCNDF & 40.72 & 45.12 & 52.27 & 41.34 & $Y=44.87$ & 19.51 \\
\hline DCADF & 31.34 & 34.87 & 43.98 & 35.11 & $\mathrm{Y}=36.32$ & 20.02 \\
\hline DCTC & 70.75 & 71.07 & 74.97 & 70.57 & $\mathrm{Y}=71.84$ & 5.73 \\
\hline DCNFC & 92.99 & 91.19 & 95.02 & 93.73 & $Y=96.23$ & 1.26 \\
\hline
\end{tabular}

According to Ribeiro et al. (2014), the ruminal degradation rate of an energy source is the main limiting factor in the use of NPN, and therefore the synchronization between the nitrogen source (protein) and energy in the rumen is essential to maximize rumen fermentation and reduce the loss of nitrogen by the rumen wall, thereby increasing the efficiency of microbial synthesis, a finding corroborated by the results of this study. Once the experimental rations showed traditional foods, which have a positive associative effect (GERON et al., 2013), and consequently a synchronization between energy and protein sources. 
The $\mathrm{pH}$ values of the rumen fluid did not differ ( $p>0.05$ ) for the inclusion levels $(0.0 \%, 0.4 \%, 0.8 \%$, and $1.2 \%$ ) of SRU in sheep feed (Table 6). However, the $\mathrm{pH}$ of the rumen fluid varied $(\mathrm{p}<0.05)$ in relation to $\mathrm{T}$ for all experimental rations (Figure $1 \mathrm{~A}$ and 1B). The average regression equation for the $\mathrm{pH}$ value of rumen liquid was $\mathrm{pH}=7.0320-0.1520 \mathrm{~T}$ $+0.0175 \mathrm{~T}^{2}$ for the different experimental rations. The minimum point estimate for the $\mathrm{pH}$ value was 6.70 at 4:18 a.m. after the morning feeding, and the maximum point calculated by the equation was 7.03 for the time $0 \mathrm{~h}$ before the morning feeding. The time obtained for the maximum $\mathrm{pH}$ value of rumen liquid estimated by equation coincides with the data shown in Table 6 , in which the mean maximum observed value was 7.08 for time $0 \mathrm{~h}$ before the morning feeding.

According to Ortolani (1981), a volume of 300 $\mathrm{mL}$ of ruminal liquid must be obtained from cattle using an esophageal catheter in order to avoid any interference with the $\mathrm{pH}$ value because volumes less than this may result in an alkalizing trend. In this study, there was great difficulty in both harvesting ruminal liquid through the gavage in the hours following food intake and collecting $100 \mathrm{~mL}$ of ruminal fluid because of the small size of sheep compared to cattle. For this reason, the $\mathrm{pH}$ value of the ruminal fluid was above 7.0 at time $0 \mathrm{~h}$ because of how the ruminal fluid was collected, as volumes of less than $300 \mathrm{~mL}$ can be contaminated by saliva, a buffer.

Table 6. Values of $\mathrm{pH}$ of the rumen fluid of sheep fed rations containing inclusion levels of slow release urea (SRU) in function of the time of collection after the morning feeding.

\begin{tabular}{cccccc}
\hline $\begin{array}{c}\text { Collection time } \\
\text { hours }\end{array}$ & \multicolumn{4}{c}{ Inclusion levels of the slowly release of urea in experimental rations } & \multirow{2}{*}{ Average } \\
\cline { 2 - 4 } & 0.0 & $0.4 \%$ & $0.8 \%$ & $1.2 \%$ & \\
\hline 0 & 7.10 & 7.08 & 7.06 & 7.07 & 7.08 \\
2 & 6.41 & 6.70 & 6.83 & 6.83 & 6.69 \\
4 & 6.66 & 6.87 & 6.75 & 6.69 & 6.74 \\
6 & 6.71 & 6.92 & 6.88 & 6.72 & 6.81 \\
8 & 6.91 & 7.00 & 6.90 & 6.77 & 6.90 \\
Average & 6.76 & 6.91 & 6.88 & 6.82 & 6.84 \\
\hline
\end{tabular}

Figure 1. Observed values (A) and regression equations (B) the $\mathrm{pH}$ of the rumen fluid of sheep fed rations containing inclusion levels of slow release urea (SRU) in function of time after feeding in the morning.

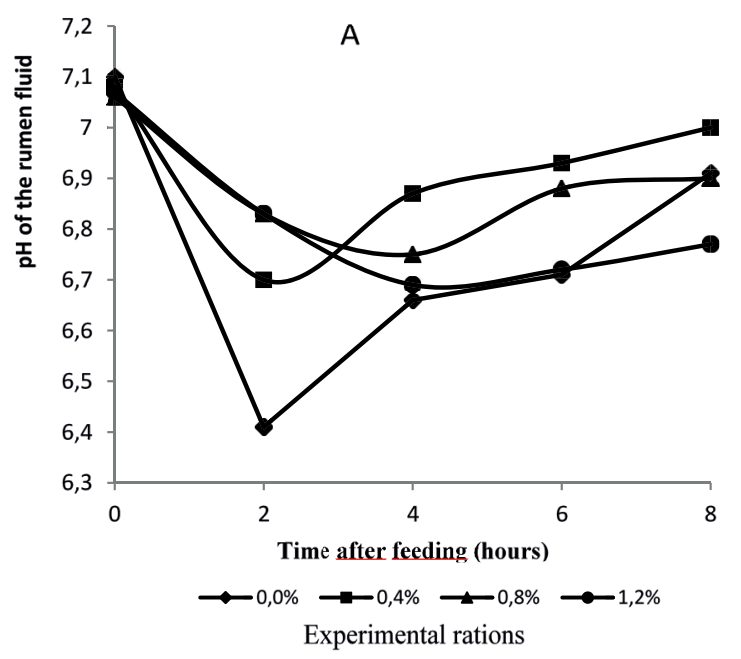

B

\begin{tabular}{lc}
\hline $\begin{array}{c}\text { Experimental } \\
\text { rations }\end{array}$ & $\begin{array}{c}\text { Equations estimated for the } \mathrm{pH} \text { of the rumen fluid of } \\
\text { sheep fed the experimental diets }\end{array}$ \\
\hline $0.0 \%$ SRU & $\mathrm{pH}=6.9997-0.2297 \mathrm{X}+0.0282 \mathrm{X}^{2}\left(\mathrm{r}^{2}=65.53 \%\right)$ \\
$0.4 \%$ SRU & $\mathrm{pH}=7.0149-0.1094 \mathrm{X}+0.0141 \mathrm{X}^{2}\left(\mathrm{r}^{2}=54.35 \%\right)$ \\
$0.8 \%$ SRU & $\mathrm{pH}=7.0394-0.1149 \mathrm{X}+0.0127 \mathrm{X}^{2}\left(\mathrm{r}^{2}=83.07 \%\right)$ \\
$1.2 \%$ SRU & $\mathrm{pH}=7.0651-0.1426 \mathrm{X}+0.0134 \mathrm{X}^{2}\left(\mathrm{r}^{2}=98.55 \%\right)$ \\
Average & $\mathrm{pH}=7.0320-0.1520 \mathrm{X}+0.0175 \mathrm{X}^{2}\left(\mathrm{r}^{2}=78.67 \%\right)$ \\
\hline
\end{tabular}


Likewise, Geron et al. (2013) obtained a maximum $\mathrm{pH}$ value of rumen fluid of 6.98 at time Oh before the morning feeding to sheep fed diets containing $20 \%, 40 \%, 60 \%$, and $80 \%$ levels of concentrate. Furthermore, the authors observed that the different concentrate levels did not alter the $\mathrm{pH}$ of the rumen fluid of sheep.

In this study, the average minimum estimated value for the ruminal $\mathrm{pH}$ was 6.70 at 4:18 a.m. after feeding, and the range of variation of ruminal $\mathrm{pH}$ values was 6.41 (at $2 \mathrm{~h}$ after meals) to 7.10 ( $0 \mathrm{~h}$ before the morning feeding). The reduction in rumen fluid $\mathrm{pH}$ may be correlated with an increased production of volatile fatty acids from the fermentation of dietary carbohydrates in the rumen (GERON et al., 2008; ZEOULA et al., 2006). Most likely, the resumption of rumen fluid $\mathrm{pH}$ to near-neutral values after the break from 4 a.m. to 4:18 a.m. was due to mechanisms buffering the $\mathrm{pH}$ of the rumen, including salivary action from the rumination of fiber, the absorption of acids by the rumen epithelium (GERON et al., 2015b), and sensory stimuli such as the viewing and smelling of food (ZEOULA et al., 2003) that may result in ruminal ammonia concentration before the sheep are fed.
An average $\mathrm{pH}$ of 6.90 (Table 6) was observed for $8 \mathrm{~h}$ after the morning feeding, a finding likely explained by the rations containing a sufficient amount of fiber to stimulate rumination and hence salivation, which has a buffering action. The experimental rations of this study showed an average of $49.65 \% \mathrm{NDF}$ and $28.82 \% \mathrm{NFC}$, which may have contributed to the rumen fluid $\mathrm{pH}$ results (Figure 1A).

The levels of SRU inclusion in sheep feed did not affect $(p>0.05)$ the concentration of $\mathrm{NH}_{3}-\mathrm{N}$ of the rumen fluid, and had no effect with respect to $\mathrm{T}$ (Table 7). The $\mathrm{NH}_{3}-\mathrm{N}$ concentration of ruminal fluid in response to the different experimental diets had an average value of $19.01 \mathrm{mg}$ of $\mathrm{NH}_{3}-\mathrm{N} 100 \mathrm{~mL}^{-1}$ of rumen fluid (Figure 2A), which remained above the optimum number of $15 \mathrm{mg} 100 \mathrm{~mL}^{-1}$ needed for maximum ruminal fermentation activity (GERON et al., 2013, 2015b; PEREIRA et al., 2009), and above the concentration of $5.0 \mathrm{mg} 100 \mathrm{~mL}^{-1}$, a limit established by the literature that does not inhibit microbial growth (PEREIRA et al., 2009). However, the $\mathrm{NH}_{3}-\mathrm{N}$ concentration in rumen liquid for all experimental diets behaved in quadratic form $(\mathrm{p}<0.05)$ in relation to $\mathrm{T}(\mathrm{h})$ after the first feed (Figure 2B).

Table 7. Ammonia nitrogen concentration values $\left(\mathrm{NH}_{3}-\mathrm{N}\right)$ from rumen fluid of sheep fed rations containing inclusion levels of slow release urea (SRU) in function of the time of collection after the morning feeding.

\begin{tabular}{cccccc}
\hline $\begin{array}{c}\text { Collection time } \\
\text { hours }\end{array}$ & \multicolumn{2}{l}{ Inclusion levels of the slowly release of urea in experimental rations } & \multirow{2}{*}{ Average } \\
\cline { 2 - 4 } & 0.0 & $0.4 \%$ & $0.8 \%$ & $1.2 \%$ & \\
\hline 0 & 17.59 & 20.39 & 24.24 & 17.90 & 20.03 \\
2 & 24.59 & 24.00 & 27.39 & 21.61 & 24.40 \\
4 & 29.05 & 31.00 & 27.48 & 28.75 & 29.07 \\
6 & 28.70 & 22.51 & 24.41 & 28.06 & 25.92 \\
8 & 16.45 & 21.38 & 20.21 & 22.09 & 20.03 \\
Average & 17.59 & 20.39 & 24.24 & 17.90 & 20.03 \\
\hline
\end{tabular}


Figure 2. Observed concentration (A) and regression equations (B) of ammonia nitrogen (NH3-N) from rumen fluid of sheep fed diets with the inclusion of levels of slow-release urea in function of time after feeding in the morning.

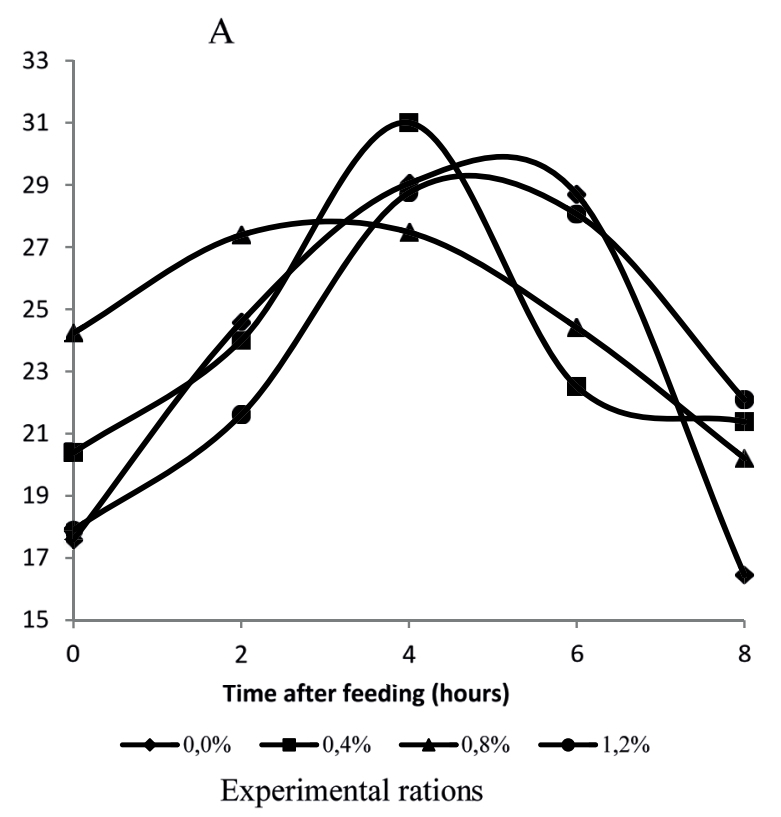

The average regression equation of the different inclusion levels of the SRU for $\mathrm{NH}_{3}-\mathrm{N}$ concentration of ruminal fluid, as a function of $\mathrm{T}$, was as follows: $\mathrm{NH}_{3}-\mathrm{N}=19.537+4.1246 \mathrm{~T}-0.5061 \mathrm{~T}^{2}$ (Figure 2B). The highest estimated concentration of $\mathrm{NH}_{3}-\mathrm{N}$ was $27.94 \mathrm{mg} 100 \mathrm{~mL}^{-1}$ of rumen fluid at 4:06 a.m. after the morning feeding, and the minimum concentration was $19.54 \mathrm{mg} 100 \mathrm{~mL}^{-1}$ of rumen fluid at $0 \mathrm{~h}$ (before the morning feeding).

The overall average observed value of $\mathrm{NH}_{3}-\mathrm{N}$ rumen fluid was $20.03 \mathrm{mg} 100 \mathrm{~mL}^{-1}$ of rumen fluid (Table 7), which remained within the optimum range of 19 to $23 \mathrm{mg} 100 \mathrm{~mL}^{-1}$ needed for maximum ruminal fermentation activity (GERON et al., 2013; ZEOULA et al., 2003), and above the concentration of $5.0 \mathrm{mg} 100 \mathrm{~mL}^{-1}$, a value established in the literature (PEREIRA et al., 2009) that does not limit microbial growth.

According to Zeoula et al. (2003), increases in ruminal ammonia concentrations before sheep are fed can be attributed in part to saliva secretion, which is stimulated even before food intake, by
$\mathrm{B}$

\begin{tabular}{lc}
\hline $\begin{array}{c}\text { Experimental } \\
\text { rations }\end{array}$ & $\begin{array}{c}\text { Equations estimated for the } \mathrm{pH} \text { of the rumen fluid of } \\
\text { sheep fed the experimental rations }\end{array}$ \\
\hline $0.0 \% \mathrm{SRU}$ & $\mathrm{NH}_{3}-\mathrm{N}=16.723+6.2786 \mathrm{X}-0.7734 \mathrm{X}^{2}\left(\mathrm{r}^{2}=93.66 \%\right)$ \\
$0.4 \% \mathrm{SRU}$ & $\mathrm{NH}_{3}-\mathrm{N}=20.191+3.5916 \mathrm{X}-0.4459 \mathrm{X}^{2}\left(\mathrm{r}^{2}=62.75 \%\right)$ \\
$0.8 \% \mathrm{SRU}$ & $\mathrm{NH}_{3}-\mathrm{N}=24.403+1.9994 \mathrm{X}-0.3189 \mathrm{X}^{2}\left(\mathrm{r}^{2}=98.77 \%\right)$ \\
$1.2 \% \mathrm{SRU}$ & $\mathrm{NH}_{3}-\mathrm{N}=16.832+4.6258 \mathrm{X}-0.4855 \mathrm{X}^{2}\left(\mathrm{r}^{2}=87.89 \%\right)$ \\
Average & $\mathrm{NH}_{3}-\mathrm{N}=19.537+4.1246 \mathrm{X}-0.5061 \mathrm{X}^{2}\left(\mathrm{r}^{2}=94.41 \%\right)$ \\
\hline
\end{tabular}

sensory stimuli such as food visualization and smell. Therefore, the handling and movement associated with weighing the food prior to delivery can condition animals, stimulate salivation, and may have caused an increase in ammonia concentration moments before feeding.

\section{Conclusion}

The inclusion of up to $0.66 \%$ of SRU in sheep feed provides better CP digestibility. The inclusion of up to $1.2 \%$ of SRU in sheep rations did not change the intake of nutrients and ruminal parameters.

\section{Acknowledgements}

The authors thank The Universidade do Estado de Mato Grosso (UNEMAT) - Campus University de Pontes e Lacerda, for fostering this research by providing the facilities of the Animal Metabolism Sector and equipment from the Food and Animal Nutrition Analysis Laboratory. 


\section{References}

AKAY, V.; TIKOFSKY, J.; HOLTZ, C. Y.; DAWSON, $\mathrm{K}$. A. Controlled release on non-protein nitrogen in the rumen. In: NUTRITIONAL BIOTECHNOLOGY IN THE FEED NA FOOD INDUSTRIES ANNUAL SYMPOSIUM, 20., 2004, Nottingham. Proceedings... Nottingham: Nottingham University Press, 2004. p. 179185.

ALVES, E. M.; MAGALHÃES, D. R.; FREITAS, M. A.; SANTOS, E. J.; PEREIRA, M. L. A.; PEDREIRA, M. S. Nitrogen metabolism and microbial synthesis in sheep fed diets containing slow release urea to replace the conventional urea. Acta Scientiarum. Animal Sciences, Maringá, v. 36, n. 1, p. 55-62, 2014a.

ALVES, E. M.; PEDREIRA, M. S.; MOREIRA, B. S.; FREIRE, L. D. R.; LIMA, T. R.; SANTOS-CRUZ, C. L. Carcass characteristics of sheep fed diets with slow-release urea replacing conventional urea. Acta Scientiarum. Animal Sciences, Maringá, v. 36, n. 3, p. 303-310, 2014b.

ASSOCIATION OF OFFICIAL ANALYTICAL CHEMISTS - AOAC. Official methods of analysis. $15^{\text {th }}$ ed. Virginia, Washington: Arlington, 1990. 1298 p.

BACH, A.; CALSAMIGLIA, S.; STERN, M. D. Nitrogen metabolism in the rumen. Journal of Dairy Science, Champaign, v. 88, n. 1, p. 9-21, 2005.

CASTANEDA, R. D.; BRANCO, A. F.; CONEGLIAN, S. M.; BARRETO, J. C.; GRANZOTTO, F.; TEIXEIRA, S. Substituição de ureia por cloreto de amônio em dietas de bovinos: digestibilidade, síntese de proteína microbiana, parâmetros ruminais e sanguíneos. Acta Scientiarum. Animal Sciences, Maringá, v. 31, n. 3, p. 271-277, 2009.

FENNER, $\mathrm{H}$. Method for determining total volatile bases in rumen fluid by steam destilation. Journal of Dairy Science, Champaign, v. 48, n. 4, p. 249-251, 1965.

GERON, L. J. V.; COSTA, F. G.; GARCIA, J.; ZANINE, A. M.; OLIVIERA, E. B.; CABRAL, L. S.; PEIRANGELI, M. A. P.; AGUIAR, S. C. Nutrients intake and digestibility in sheep fed with residue from the extraction of tamarind pulp. Semina: Ciências Agrárias, Londrina, v. 36, n. 6, p. 4401-4412, 2015a. Suplemento 2.

GERON, L. J. V.; GARCIA, J.; COSTA, F. G.; AGUIAR, S. C.; OLIVEIRA, E. B.; SILVA, M. I. L.; CABRAL, L. S.; PIERANGELI, M. A. P.; ZEOULA, L. M.; MEXIA, A. A. Ruminal parameters and nitrogen balance in sheep fed diets containing residue from the extraction of tamarind pulp. Semina: Ciências Agrárias, Londrina, v. 36, n. 5, p. 3411-3420, 2015 b.
GERON, L. J. V.; MEXIA, A. A.; CRISTO, R. L.; GARCIA， J.; CABRAL， L. S.; TRAUTAMANN, R. J.; MARTINS, O. S.; ZEOULA, L. M. Consumo, digestibilidade dos nutrientes e características ruminais de cordeiros alimentados com níveis crescentes de concentrado em ambiente tropical no Vale do Alto Guaporé - MT. Semina: Ciências Agrárias, Londrina, v. 34, n. 5, p. 2497-2510, 2013.

GERON, L. J. V.; ZEOULA, L. M.; ERKEL, J. A.; PRADO, I. N.; JONKER, R. C.; GUIMARÃES, K. C. Coeficiente de digestibilidade e características ruminais de bovinos alimentados com rações contendo resíduo de cervejaria fermentado. Revista Brasileira de Zootecnia, Viçosa, MG, v. 37, n. 9, p. 1685-1695, 2008.

MARTHA, G. O. D. Substituição do farelo de soja por ureia encapsulada em suplementos proteinados para bovinos de corte. 2013. Dissertação (Mestrado em Ciências Animal) - Faculdade de Medicina Veterinária e Zootecnia. Universidade Federal de Mato Grosso do Sul, Campo Grande.

MENDES, C. Q.; FERNANDES, R. H. R.; SUSIN, I.; PIRES, A. V.; GENTIL, R. S. Substitituição parcial do farelo de soja por ureia ou amireia na alimentação de cabras em lactação. Revista Brasileira de Zootecnia, Viçosa, MG, v. 39, n. 8, p. 1818-1824, 2010.

NATIONAL RESEARCH COUNCIL - NRC. Nutrient requeriments of small ruminants: sheep, goats, cervids, and new world camelids. Washington D. C.: National Academy Press, 2007. 362 p.

OLIVEIRA, A. S.; VALADARES, R. F. D.; VALADARES FILHO, S. D.; CECON, P. R.; RENNÓ, L. N.; QUEIROZ, A. C.; CHIZZOTTI, M. L. Produção de proteína microbiana e estimativas das excreções de derivados de purinas e de ureia em vacas lactantes alimentadas com rações isoproteicas contendo diferentes níveis de compostos nitrogenados não-proteicos. Revista Brasileira de Zootecnia, Viçosa, MG, v. 30, n. 5, p. 16211629, 2001.

ORTOLANI, E. L. Considerações técnicas sobre o uso da sonda esofágica na colheita do suco de rúmen de bovinos para mensuração do pH. Arquivo da Escola Veterinária, Belo Horizonte, v. 33, n. 2, p. 269-275, 1981.

PARIS, W.; MARCHESAN, R.; PROHMANN, P. E. F.; GLASENAPP, M.; ZANOTTI, J.; HARTMANN, D. V. Utilização de ureia de liberação lenta ems al mineral na suplementação de bovinos de corte em pastagem de Tifton 85. Semina: Ciências Agrárias, Londrina, v. 34, n. 1, p. 409-418, 2013. 
PEREIRA, E. P.; MIZUBUTI, I. Y.; VILLARROEL, A. B. S.; OLIVEIRA, S. M. P.; PIMENTEL, P. G. Variáveis ruminais em novilhos alimentados com feno de tifton 85 com diferentes tamanhos de partículas. Semina: Ciências Agrárias, Londrina, v. 30, n. 1, p. 243-250, 2009.

PIRES, A. V.; OLIVEIRAJUNIOR, R. C.; FERNANDES, J. J. R.; SUSIN, I.; SANTOS, A.A.P.; ARAÚJO, R.C.; GOULART, R.C.D. Substituição do farelo de soja por ureia ou amireia na dieta de bovinos de corte confinados. Pesquisa Agropecuária Brasileira, Brasília, v. 39, n. 9, p. 937-942, 2004.

PRADO, O. P. P.; ZEOULA, L. M.; CALDAS NETO, S. F.; GERON, L. J. V.; FERELI, F.; MAEDA, E. M.; OLIVEIRA, F. C. L.; KAZAMA, R. Digestibilidade dos nutrientes de rações com diferentes níveis de proteína degradável no rúmen e fonte de amido de alta degradabilidade ruminal em ovinos. Acta Scientiarum. Animal Sciences, Maringá, v. 26, n. 4, p. 521-527, 2004.

PUGA, D. C.; GALINA, H. M.; PERÉZ-GIL, R. F.; SANGINES, G. L. AGUILERA, B. A.; BARAJAS, C. R.; HERRERA, H. J. Effect of a controlled-release urea supplementation on feed intake, digestibility, nitrogen balance and ruminal kinetics off sheep fed low quality tropical forage. Small Ruminant Reseach, Amsterdam, v. 41, n. 1, p. 9-18, 2001.

RIBEIRO, P. R.; MACEDO JUNIOR, G. L.; SILVA, S. P. Aspectos nutricionais da utilização das proteínas pelos ruminantes. Veterinária notícias, Uberlândia, v. 20, n. 2, p. 1-14, 2014.

SILVEIRA, V. A.; LOPES, N. M.; OLIVEIRA, R. C.; GONZALES, B.; SIQUEIRA, A. V.; BIER, L. P. P.; ZONI, M. S.; GIARDINI, W.; PEREIRA, R. A. N.; ALMEIDA, R.; PEREIRA, M. N. Substituição parcial de farelo de soja por ureia de liberação lenta (ULL) em rebanhos leiteiros comerciais. Revista Brasileira de Saúde e Produção Animal, Salvador, v. 13, n. 2, p. 383395, 2012.

SNIFFEN, C. J.; O'CONNOR, J. D.; VAN SOEST, P. J. A net carbohydrate and protein system for evaluating cattle diets II. Carbohydrate and protein availability. Journal of Animal Science, Champaing, v. 70, n. 11, p. 3562-3577, 1992.

SOUZA, O. M.; MARTINS, E. N.; ROSSI, R. M.; OLIVEIRA, C. A. L.; AGUIAR, S. C.; PAULA, E. J. H.; GERON, L. J. V.; STIVANIN, T. E.; FERREIRA, E. B. Ruminal $\mathrm{pH}$ and $\mathrm{N}-\mathrm{NH}_{3}$ behavior: a Bayesian approach. Semina: Ciências Agrárias, Londrina, v. 37, n. 1, p. 311320, 2016.
SOUZA, V. L. S.; ALMEIDA, R.; SILVA, D. F. F. S.; PIEKARKI, P. R. B.; JESUS, C. P. Substituição parcial de farelo de soja por ureia protegida na produção e composição de leite. Arquivo Brasileiro de Medicina Veterinária e Zootecnia, Belo Horizonte, v. 62, n. 6, p. 1415-1422, 2010.

TAYLOR-EDWARDS, C. C.; HIBBARD, G.; KITTSMORGAN, S.; HARMON, D. L. Effects of slow-release urea on ruminal digesta characteristics and growth performance in beef steers. Journal of Animal Science, Champaing, v. 87, n. 1, p. 200-208, 2009.

UNIVERSIDADE FEDERAL DE VIÇOSA - UFV. Sistemas de Análises Estatísticas e Genéticas - SAEG. Versão 9. 1. Manual do usuário. Viçosa, MG: Imprensa Universitária, 2007. 150 p.

VAN SOEST, P. J.; ROBERTSON, J. B.; LEWIS, B. A. Methods for dietary fiber neutral detergent fiber, and no starch polysaccharides in relation to animal nutrition. Journal of Dairy Science, Champaing, v. 74, n. 12, p. 3583-3597, 1991.

VIEIRA, P. F. Efeito do formaldeído na proteção de proteínas e lipídios em rações para ruminantes. 1980. Tese (Doutorado em Zootecnia) - Universidade Federal de Viçosa, Viçosa, MG.

XIN, H. S.; SCHAEFER, D. M.; LIU, Q. P.; AXE, D. E.; MENG, Q. X. Effects of polyurethane coated urea supplement on in vitro ruminal fermentation, ammonia release dynamics and lactating performance of Holstein dairy cows fed a steam-flaked corn-based diet. Asian and Australian Journal of Animal Science, Gwanak-gu, Seoul, v. 23, n. 4, p. 491-500, 2010.

ZEOULA, L. M.; CALDAS NETO, S. F.; GERON, L. J. V.; MAEDA, E. M.; PRADO, I. N.; DIAN, P. H. M. Substituição do milho pela farinha de varredura de mandioca (Manihot esculenta, Crantz) em rações de ovinos: consumo, digestibilidade, balanços de nitrogênio e energia e parâmetros ruminais. Revista Brasileira de Zootecnia, Viçosa, MG, v. 32, n. 2, p. 491-502, 2003.

ZEOULA, L. M.; FERELI, F.; PRADO, I. N.; GERON, L. J. V.; CALDAS NETO, S. F.; PRADO, O. P. P.; MAEDA, E. M. Digestibilidade e balanço de nitrogênio com diferentes teores de proteína degradável no rúmen e milho como fonte de amido em ovinos. Revista Brasileira de Zootecnia, Viçosa, MG, v. 35, n. 5, p. 2179-2186, 2006. 
